\title{
Heterocyclic Dicyanovinyl Derivatives: Synthesis and Evaluation of the Chemosensory Ability in Aqueous Solution ${ }^{+}$
}

\author{
Rosa Cristina M. Ferreira, Susana P. G. Costa and Maria Manuela M. Raposo * \\ Centro de Química, Universidade do Minho, Campus de Gualtar, 4710-057 Braga, Portugal; \\ crisferreira44103@hotmail.com (R.C.M.F.); spc@quimica.uminho.pt (S.P.G.C.); \\ * Correspondence: mfox@quimica.uminho.pt \\ + Presented at the 3rd International Electronic Conference on Sensors and Applications, \\ 15-30 November 2016; Available online: https://sciforum.net/conference/ecsa-3.
}

Published: 14 November 2016

\begin{abstract}
Two novel dicyanovinyl derivatives $\mathbf{3 a}-\mathbf{b}$ were synthesized in moderate to good yields through a Knoevenagel reaction of the corresponding aldehyde precursors and malononitrile. The photophysical properties of the new push-pull systems were studied by UV-vis and fluorescence spectroscopy in acetonitrile. The evaluation of the compounds as colorimetric chemosensors was carried out by performing spectrophotometric titrations in acetonitrile and acetonitrile/water in the presence of relevant organic and inorganic anions, and of alkaline, alkaline-earth and transition metal cations. The benzoindole derivative exhibited great selectivity for the cyanide anion over other anions in acetonitrile/water (8:2) solution showing a distinct color change from colorless to yellow.
\end{abstract}

Keywords: Knoevenagel reaction; benzofuran; benzoindole; push-pull dicyanovinyl heterocyclic compounds; colorimetric sensors; aqueous media

\section{Introduction}

The cyanide anion is well known due to its toxicity to the environment and to mammals, leading to convulsions, loss of consciousness, and eventual death. It is lethal to humans in concentrations in the range of $0.5-3.5 \mathrm{mg}$ per $\mathrm{Kg}$ of body weight. In addition to being found in many foods and plants, cyanides are used industrially in the synthesis of organic chemicals, polymers, metallurgy as well as in gold mining [1-4].

Consequently, selective detection and quantification of cyanide is very important and it has been the object of increasing investigation. A large number of fluorimetric and/or colorimetric chemosensors as well as dosimeters, capable of detecting this anion in organic solvents as well as in aqueous mixtures have been reported during the last decade. Even so, the majority suffer from several drawbacks such as difficult synthesis, poor selectivity, only work in an organic media and the use of instrumentation is required [5]. Therefore, the research on versatile and tunable chemosensors capable of selective and sensitive colorimetric sensing of the cyanide anion, especially in mixed aqueous solutions, is still a challenge [6-11].

Having in mind the work developed in our research group concerning push-pull dicyanovinyl derivatives for several optical applications (SHG and TPA NLOphores) [12-15], we report in this work, the synthesis, characterization and evaluation of the photophysical properties and the chemosensory ability of novel optical chemosensors based on benzofuran and benzoindole systems functionalized with the dicyanovinyl group. 


\section{Experimental}

\subsection{General Procedure for the Synthesis of Dicyanovinyl Derivatives 3a-b}

A solution of aldehyde $\mathbf{2 a}$ or $\mathbf{2} \mathbf{b}(0.37 \mathrm{mmol})$, malononitrile $\mathbf{1}(0.37 \mathrm{mmol})$ and piperidine (1 drop) in ethanol $(5 \mathrm{~mL})$ was heated at reflux for $5 \mathrm{~h}$. After this time the solvent was evaporated and the resulting crude products were purified by column chromatography (silica gel, petroleum ether/dichloromethane (1:1)).

\subsubsection{2-((1H-Benzo[g]indol-3- $y l)$ methylene)malononitrile 3a}

Compound 3a was obtained as a light yellow solid (40 mg, 65\%). Mp $>300{ }^{\circ} \mathrm{C}$. UV-vis (acetonitrile): $\lambda_{\max } \mathrm{nm}(\log \varepsilon) 374$ (4.40). ${ }^{1} \mathrm{H}-\mathrm{NMR}$ (DMSO- $\left.d_{6}\right): \delta=7.52(\mathrm{dt}, J=8.0$ and $1.2 \mathrm{~Hz}, 1 \mathrm{H}, \mathrm{H}-7)$, $7.64(\mathrm{dt}, J=8.0$ and $1.2 \mathrm{~Hz}, 1 \mathrm{H}, \mathrm{H}-8), 7.74(\mathrm{~d}, J=8.8 \mathrm{~Hz}, 1 \mathrm{H}, \mathrm{H}-5), 8.0(\mathrm{~d}, J=8.0 \mathrm{~Hz}, 1 \mathrm{H}, \mathrm{H}-6), 8.11(\mathrm{~d}, J$ $=8.8 \mathrm{~Hz}, 1 \mathrm{H}, \mathrm{H}-4), 8.41(\mathrm{~d}, J=8.4 \mathrm{~Hz}, 1 \mathrm{H}, \mathrm{H}-9), 8.49(\mathrm{~s}, 1 \mathrm{H}, \mathrm{H}-2), 8.82(\mathrm{~s}, 1 \mathrm{H}, \mathrm{CH}=\mathrm{C}), 13.55(\mathrm{~s}, 1 \mathrm{H}, \mathrm{NH})$ ppm. ${ }^{13} \mathrm{C}-\mathrm{NMR}$ (DMSO- $\left.d_{6}\right): \delta=70.91\left(\underline{\mathrm{C}}-(\mathrm{CN})_{2}\right), 112.38(\mathrm{C}-3 \mathrm{a}), 115.64(\mathrm{C} \equiv \mathrm{N}), 115.71(\mathrm{C} \equiv \mathrm{N}), 118.18(\mathrm{C}-$ 4), 120.76 (C-9), 121.61 (C-9a), 123.28 (C-5), 123.39 (C-3), 125.14 (C-7), 126.57 (C-8), 128.62 (C-6), 129.91 (C-2), 130.70 (C-5a), 131.17 (C-3b), 153.05 ( $\underline{\mathrm{CH}}=\mathrm{C}) \mathrm{ppm}$.

\subsubsection{2-((Benzofuran-2-yl)methylene)malononitrile $3 \mathrm{~b}$}

Compound $\mathbf{3 b}$ was obtained as a yellow solid (49 $\mathrm{mg}, 74 \%)$. Mp 170.9-171.5 ${ }^{\circ} \mathrm{C}$. UV-vis (acetonitrile): $\lambda_{\max } \mathrm{nm}(\log \varepsilon) 361$ (4.61). ${ }^{1} \mathrm{H}-\mathrm{NMR}$ (DMSO- $\left.d_{6}\right): \delta=7.40(\mathrm{dt}, J=8.0$ and $1.2 \mathrm{~Hz}, 1 \mathrm{H}, \mathrm{H}-5)$, $7.60(\mathrm{dt}, J=8.4$ and $1.2 \mathrm{~Hz}, 1 \mathrm{H}, \mathrm{H}-6), 7.70(\mathrm{dd}, J=8.8$ and $0.8 \mathrm{~Hz}, 1 \mathrm{H}, \mathrm{H}-7), 7.83(\mathrm{~s}, 1 \mathrm{H}, \mathrm{H}-3), 7.88$ (dd, $J=8.0$ and $1.2 \mathrm{~Hz}, 1 \mathrm{H}, \mathrm{H}-4), 8.48(\mathrm{~s}, 1 \mathrm{H}, \mathrm{CH}=\mathrm{C})$ ppm. ${ }^{13} \mathrm{C}-\mathrm{NMR}\left(\mathrm{DMSO}-d_{6}\right): \delta=78.67\left(\mathrm{C}-(\mathrm{CN})_{2}\right), 111.99$ (C-7), $113.07(\mathrm{C} \equiv \mathrm{N}), 114.35$ (C $\equiv N), 121.34$ (C-3), 123.92 (C-4), 124.70 (C-5), 127.09 (C-3a), 130.25 (C-6), $145.44(\underline{\mathrm{C}} \mathrm{H}=\mathrm{C}), 148.98$ (C-2), 156.14 (C-7a) ppm.

\subsection{Spectrophotometric Titrations of Compounds $\mathbf{3} \mathbf{a}-\mathbf{b}$}

UV-visible absorption spectra $(250-650 \mathrm{~nm})$ were obtained using a Shimadzu UV/2501PC spectrophotometer. Fluorescence spectra were collected using a FluoroMax-4 spectrofluorometer. The relative fluorescence quantum yields were determined by using $10^{-6} \mathrm{M}$ solution of Rhodamine 6G in ethanol as standard $\left(\Phi_{\mathrm{F}}=0.95\right)$ [16]. Organic solvents used in the spectroscopic studies were of spectroscopic grade. Solutions of derivatives $3 \mathbf{a}-\mathbf{b}$ (ca. $1.0 \times 10^{-5} \mathrm{M}$ ) and of the ions under study (ca. $1.0 \times 10^{-2}$ and $1.0 \times 10^{-3} \mathrm{M}$ ) were prepared in UV-grade acetonitrile or acetonitrile/water (8:2). Titrations of the compounds $3 \mathbf{a}-\mathbf{b}$ in the presence of relevant organic and inorganic anions $\left(\mathrm{AcO}^{-}, \mathrm{F}^{-}\right.$, $\left.\mathrm{Cl}^{-}, \mathrm{Br}^{-}, \mathrm{CN}^{-}, \mathrm{NO}_{3}^{-}, \mathrm{BzO}^{-}, \mathrm{H}_{2} \mathrm{PO}_{4}^{-}, \mathrm{HSO}_{4}^{-}\right)$, and of alkaline, alkaline-earth and transition metal cations $\left(\mathrm{Cu}^{2+}, \mathrm{Cd}^{2+}, \mathrm{Pd}^{2+}, \mathrm{Ni}^{2+}, \mathrm{Hg}^{2+}, \mathrm{Zn}^{2+}, \mathrm{Fe}^{2+}, \mathrm{Fe}^{3+}\right.$ and $\left.\mathrm{Cr}^{3+}\right)$ was performed by the sequential addition of the ion stock solution to the dicyanovinyl solution, in a $10 \mathrm{~mm}$ path length quartz cuvette and absorption emission spectra were measured by excitation at the wavelength of maximum absorption for each compound, with a $2 \mathrm{~nm}$ slit.

\section{Results and Discussion}

\subsection{Synthesis and Characterization}

Dicyanovinyl 3a-b were synthesized in moderate to good yields $(65 \%-74 \%)$, by a Knoevenagel reaction between malononitrile $\mathbf{1}$ and aldehydes $\mathbf{2 a} \mathbf{a} \mathbf{b}$. The new compounds were completely characterized by the usual spectroscopic techniques (Scheme 1, Table 1). 
<smiles>O=Cc1c[nH]c2c1ccc1ccccc12</smiles>

$2 a$<smiles>O=Cc1cc2ccccc2o1</smiles>

2b<smiles>N#CC(C#N)=Cc1c[nH]c2c1ccc1ccccc12</smiles>

3a<smiles>N#CC(C#N)=Cc1cc2ccccc2o1</smiles>

Scheme 1. Synthesis of dicyanovinyl derivatives $\mathbf{3 a - b}$.

The absorption and emission spectra of compounds $\mathbf{3} \mathbf{a}-\mathbf{b}$ were measured in acetonitrile solutions and showed intense lowest energy charge-transfer absorption bands in the UV-visible region between 361 and $374 \mathrm{~nm}$ (absorption). Both compounds were very weakly fluorescent, with wavelengths of maximum emission close to $405-528 \mathrm{~nm}$ and with relative fluorescence quantum yields in the order of 0.005 .

Table 1. Yields, UV-visible absorption and emission data for dicyanovinyls $\mathbf{3 a} \mathbf{a}-\mathbf{b}$ in acetonitrile solution.

\begin{tabular}{ccccccc}
\hline & \multirow{2}{*}{$\eta(\%)$} & \multicolumn{2}{c}{ Absorption } & \multicolumn{3}{c}{ Emission } \\
\cline { 3 - 7 } & $\lambda_{\max }(\mathbf{n m})$ & $\log \varepsilon$ & $\lambda_{\text {em }}(\mathbf{n m})$ & Stokes' Shift (nm) & $\boldsymbol{\Phi}_{\text {Flu }}$ \\
\hline 3a & 65 & 374 & 4.40 & 528 & 154 & 0.006 \\
\hline 3b & 74 & 361 & 4.61 & 405 & 44 & 0.005 \\
\hline
\end{tabular}

\subsection{Spectrophotometric Titrations of Dicyanovinyl Derivatives 3a-b with Anions and Metallic Ions}

Evaluation of new dicyanovinyl $3 \mathbf{a}-\mathbf{b}\left(10^{-5} \mathrm{M}\right)$ as colorimetric chemosensors were carried out in $\mathrm{ACN}$ and $\mathrm{ACN} / \mathrm{H}_{2} \mathrm{O}$ solutions, in the presence of several ions $\left(\mathrm{AcO}^{-}, \mathrm{F}^{-}, \mathrm{Cl}^{-}, \mathrm{Br}^{-}, \mathrm{CN}^{-}, \mathrm{NO}_{3}^{-}, \mathrm{BzO}^{-}\right.$, $\mathrm{H}_{2} \mathrm{PO}_{4}^{-}, \mathrm{HSO}_{4}^{-}, \mathrm{Cu}^{2+}, \mathrm{Cd}^{2+}, \mathrm{Pd}^{2+}, \mathrm{Ni}^{2+}, \mathrm{Hg}^{2+}, \mathrm{Zn}^{2+}, \mathrm{Fe}^{2+}, \mathrm{Fe}^{3+}$ and $\mathrm{Cr}^{3+}$ ) with biological, environmental and analytical relevance.

Preliminary tests were carried out by addition of up to 50 equiv of each ion to the solutions of dicyanovinyls $3 \mathbf{a}-\mathbf{b}$ in $\mathrm{ACN}$ and in aqueous mixture $\mathrm{ACN} / \mathrm{H}_{2} \mathrm{O}(8: 2)$, revealing that only compound 3a exhibited chemosensor ability.

It was found that 3a displayed a marked colour change, from colourless to yellow, upon interaction with $\mathrm{AcO}, \mathrm{F}^{-}, \mathrm{CN}^{-}, \mathrm{BzO}^{-}$and $\mathrm{H}_{2} \mathrm{PO}_{4}^{-}$in acetonitrile solution. Moreover, 3a showed selectivity for the cyanide ion in aqueous mixture displaying the same colour change (Figure 1).

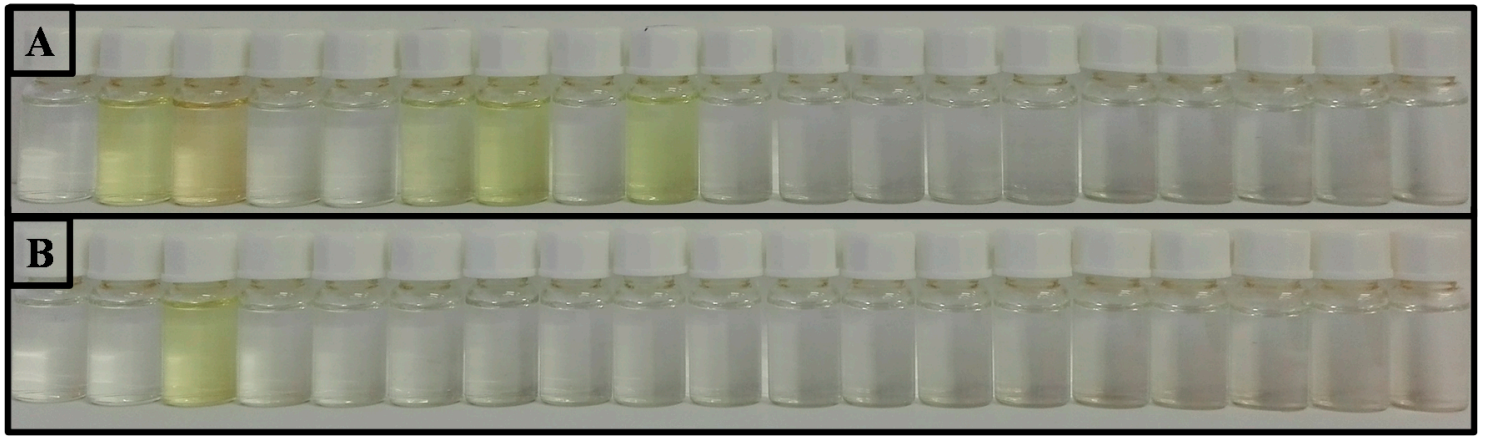

Figure 1. Colour changes of compound $3 a\left(10^{-4} \mathrm{M}\right.$ in (A): $\left.\mathrm{ACN},(\mathbf{B}): \mathrm{ACN} / \mathrm{H}_{2} \mathrm{O}(8: 2)\right)$ in the presence of 50 equiv. of $\mathrm{AcO}^{-}, \mathrm{CN}^{-}, \mathrm{HSO}_{4}^{-}, \mathrm{NO}_{3}{ }^{-}, \mathrm{H}_{2} \mathrm{PO}_{4}^{-}, \mathrm{F}^{-}, \mathrm{Cl}^{-}, \mathrm{BzO}^{-}, \mathrm{Cu}^{2+}, \mathrm{Pd}^{2+}, \mathrm{Zn}^{2+}, \mathrm{Fe}^{2+}, \mathrm{Hg}^{2+}, \mathrm{Fe}^{3+}, \mathrm{Co}^{2+}$, $\mathrm{Ca}^{2+}, \mathrm{Na}^{+}$and $\mathrm{Ni}^{2+}$ (in the form of tetrafluorborate or perchlorate salts). 
Considering these preliminary results, spectrophotometric titration of compound 3a in ACN with these selected ions were undertaken. Titration with $\mathrm{CN}^{-}$revealed a trend in the UV-Vis spectra, the intensity of the longest wavelength absorption band at $373 \mathrm{~nm}$ decreased progressively upon addition of the anion, with the simultaneous growth of a new red-shifted absorption band located at $424 \mathrm{~nm}$ (Figure 2). It can be seen that a very small amount of cyanide ion (0.3 equiv) caused large changes in the absorption spectrum and a drastic color change in the solution of compound 3a.

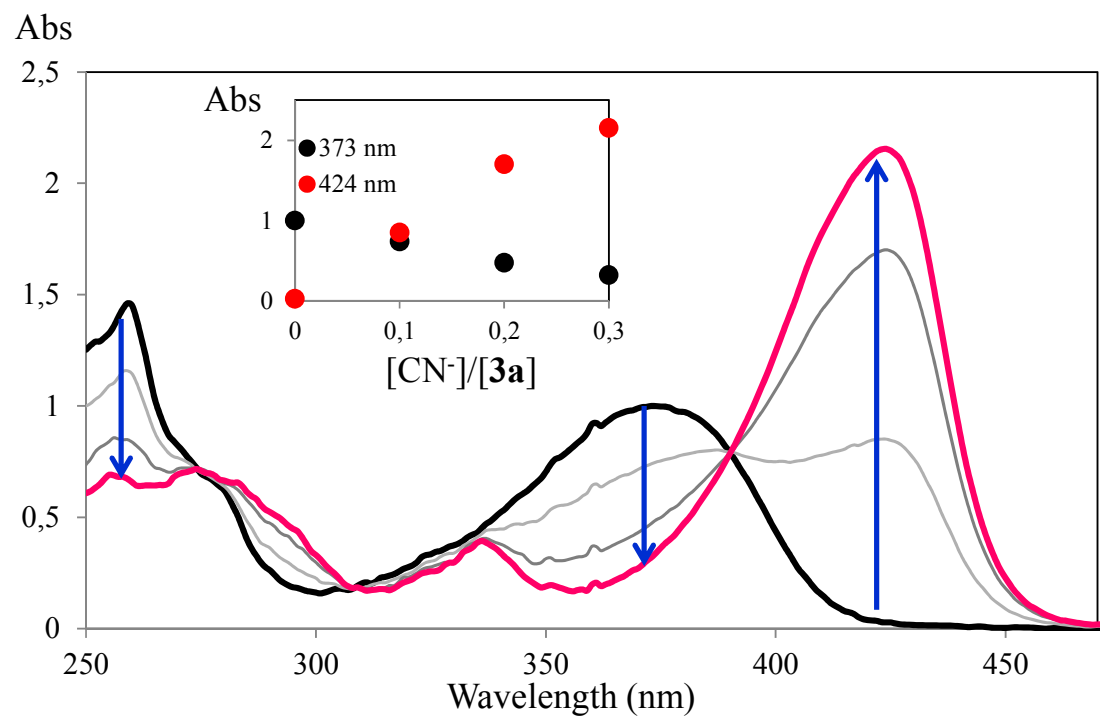

Figure 2. Spectrophotometric titrations of compound 3a with addition of increasing amounts of $\mathrm{CN}^{-}$ in ACN. The inset represents the normalized absorption ([3a] $\left.=1 \times 10^{-5} \mathrm{M}, \mathrm{T}=298 \mathrm{~K}\right)$.

Compound 3a, in the titration with $\mathrm{F}^{-}, \mathrm{AcO}^{-}, \mathrm{H}_{2} \mathrm{PO}_{4}{ }^{-}$and $\mathrm{BzO}^{-}$, revealed the same trend observed in the titration with cyanide ion (Figure 3 ). In the titration with $\mathrm{F}^{-} 0.4$ equiv were used, 1 equiv was needed for titration with $\mathrm{AcO}^{-}$, and 5 equiv for the titration with $\mathrm{H}_{2} \mathrm{PO}_{4}^{-}$and $\mathrm{BzO}^{-}$. Thus, although not selective, compound $\mathbf{3 a}$ in acetonitrile was more sensitive to the presence of cyanide ion, considering that only 0.3 equiv of the cyanide ion were required for the visible colour change.
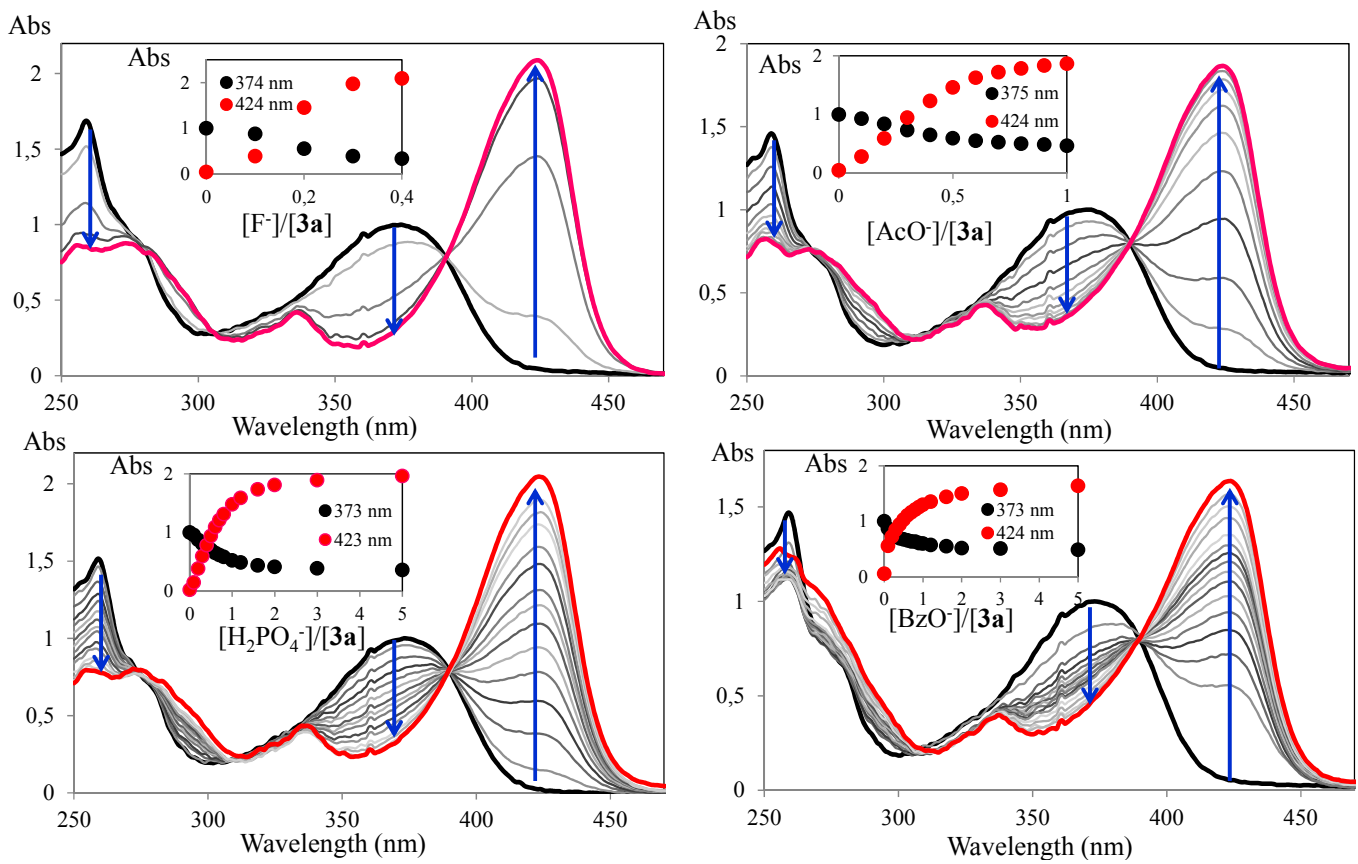

Figure 3. Spectrophotometric titration of 3a with addition of increasing amounts of $\mathrm{F}^{-}, \mathrm{AcO}^{-}, \mathrm{H}_{2} \mathrm{PO}_{4}^{-}$and $\mathrm{BzO}^{-}$in $\mathrm{ACN}$. The inset represents the normalized absorption a $373 \mathrm{~nm}\left([3 \mathrm{a}]=1 \times 10^{-5} \mathrm{M}, \mathrm{T}=298 \mathrm{~K}\right)$. 
Spectrophotometric titrations of compound 3a in $\mathrm{ACN} / \mathrm{H}_{2} \mathrm{O}(8: 2)$ confirmed the preliminary sensing results, with compound 3a being selective for the cyanide ion although it required a larger amount of ion to achieve a similar colour change (70 equiv), when compared to the titration in ACN. In Figure 4 it can be seen that there was a gradual decrease in absorption intensity upon addition of the cyanide ion, accompanied by a red-shift with the formation of a new band at $417 \mathrm{~nm}$.

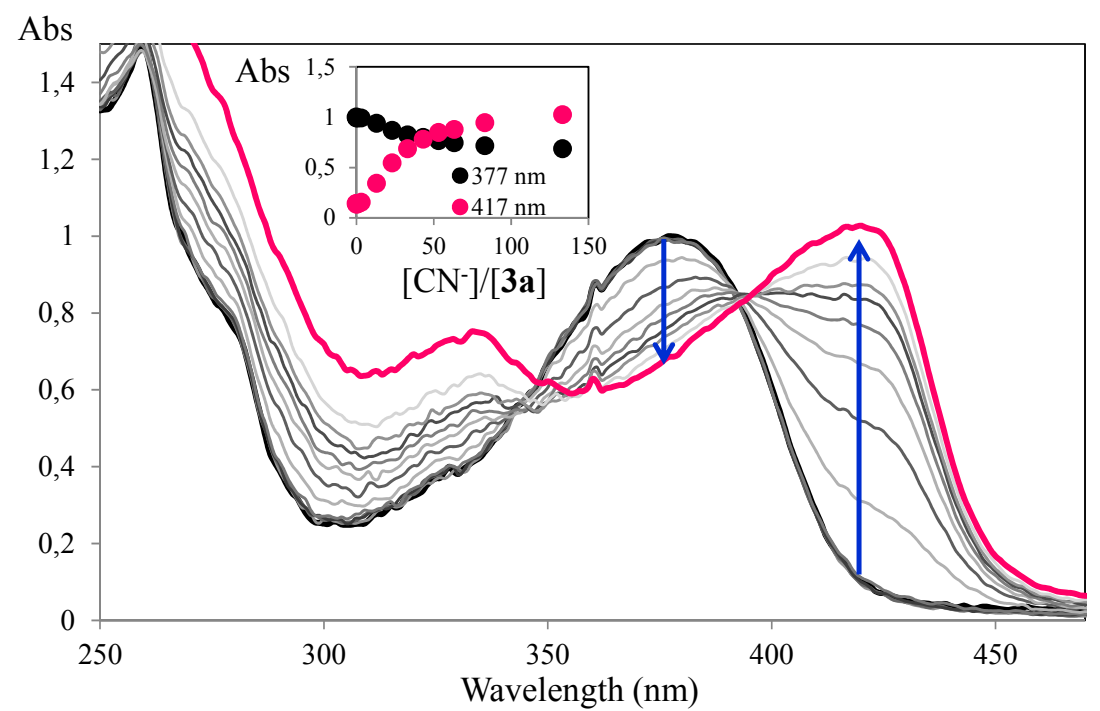

Figure 4. Spectrophotometric titration of compound 3a with addition of increasing amounts of $\mathrm{CN}^{-}$ in $\mathrm{ACN} / \mathrm{H}_{2} \mathrm{O}$ (8:2). The inset represents the normalized emission ([3a] $]=1 \times 10^{-5} \mathrm{M}, \mathrm{T}=298 \mathrm{~K}$ ).

\section{Conclusions}

The synthesis of new dicyanovinyls $\mathbf{3} \mathbf{a}-\mathbf{b}$ was achieved in moderate to good yields by a simple experimental procedure. The sensory ability was evaluated for several ions by spectrophotometric titrations in acetonitrile and acetonitrile/water. Compound 3a was selective for the cyanide ion in $\mathrm{ACN} / \mathrm{H}_{2} \mathrm{O}(8: 2)$, which is a very promising result as a colorimetric chemosensor for application in aqueous media.

Acknowledgments: Thank are due to Fundação para a Ciência e Tecnologia (Portugal) and FEDER-COMPETE for financial support through Centro de Química (UID/QUI/00686/2013 and UID/QUI/0686/2016), and a PhD grant to R.C.M. Ferreira (SFRH/BD/86408/2012). The NMR spectrometer Bruker Avance III 400 is part of the National NMR Network and was purchased with funds from FCT and FEDER.

Conflicts of Interest: The authors declare no conflict of interest.

\section{References}

1. Vennesland, B.; Comm, E.E.; Knownles, C.J.; Westly, J.; Wissing, F. Cyanide in Biology; Academic Press: London, UK, 1981.

2. Bohnet, M. (Ed.) Ullmann's Encyclopedia of Industrial Chemistry, 6th ed.; Wiley-VCH: New York, NY, USA, 2003.

3. Muir, G. Hazards in the Chemical Laboratory; Royal Chemical Society: London, UK, 1977.

4. Baskin, S.I.; Brewer, T.G. Medical Aspects of Chemical and Biological Warfare; Sidel, F., Takafuji, E.T., Franz, D.R., Eds.; TMM Publications: Washington, DC, USA, 1997; p. 271.

5. Xu, Z.; Chen, X.; Kim, H.N.; Yoon, J. Sensors for the optical detection of cyanide ion. Chem. Soc. Rev. 2010, $39,127$.

6. Batista, R.M.F.; Costa, S.P.G.; Raposo, M.M.M. Selective colorimetric and fluorimetric detection of cyanide in aqueous solution using novel heterocyclic imidazo-anthraquinones. Sens. Actuators B Chem. 2014, 191, 791.

7. Batista, R.M.F.; Oliveira, E.; Costa, S.P.G.; Lodeiro, C.; Raposo, M.M.M. Cyanide and fluoride colorimetric sensing by novel imidazo-anthraquinones functionalized with indole and carbazole. Supramol. Chem. 2014, 26,71 . 
8. Batista, R.M.F.; Costa, S.P.G.; Raposo, M.M.M. J. Photochem. Photobiol. Chem. A 2013, 259, 733.

9. Santos-Figueroa, L.E.; Moragues, M.E.; Raposo, M.M.M.; Batista, R.M.F.; Ferreira, R.C.M.; Costa, S.P.G.; Sancenón, F.; Martínez-Máñez, R.; Ros-Lis, J.V.; Soto, J. Synthesis and evaluation of thiosemicarbazones functionalized with furyl moieties as new chemosensors for anion recognition. Org. Biomol. Chem. 2012, 10, 7418.

10. Santos-Figueroa, L.E.; Moragues, M.E.; Raposo, M.M.M.; Batista, R.M.F.; Ferreira, R.C.M.; Costa, S.P.G.; Sancenón, F.; Martínez-Máñez, R.; Ros-Lis, J.V.; Soto, J. Synthesis and evaluation of fluorimetric and colorimetric chemosensors for anions based on (oligo)thienyl-thiosemicarbazones. Tetrahedron 2012, 68, 7179.

11. Raposo, M.M.M.; García-Acosta, B.; Ábalos, T.; Calero; P.; Martínez-Manez, R.; Ros-Lis, J.V.; Soto, J. Synthesis and study of the use of heterocyclic thiosemicarbazones as signalling scaffolding for the recognition of anions.J. Org. Chem. 2010, 75, 2922.

12. Raposo, M.M.M.; Herbivo, C.; Hugues, V.; Clermont, G.; Castro, M.C.R.; Comel, A. Blanchard-Desce, M. Synthesis, fluorescence and two-photon absorption properties of push-pull 5-aryl[3,2-b]thienothiophene derivatives. Eur. J. Org. Chem. 2016, 31, 5263-5273.

13. Castro, M.C.R.; Belsley, M.; Raposo, M.M.M. Push-pull second harmonic generation (SHG) chromophores bearing pyrrole and thiazole heterocycles functionalized with strong acceptor moieties: syntheses and characterization. Dyes Pigments 2016, 128, 89-95.

14. Castro, M.C.R.; Belsley, M.; Raposo, M.M.M. Synthesis and characterization of push-pull (bi)thienylpyrrole NLOphores with enhanced hyperpolarizabilities. Dyes Pigments 2016, 131, 333-335.

15. Genin, E.; Hugues, V.; Clermont, G.; Herbivo, C.; Comel, A.; Castro, M.C.R.; Raposo, M.M.M.; BlanchardDesce, M. Fluorescence and two-photon absorption of push-pull aryl(bi)thiophenes: structure-property relationships. Photochem. Photobiol. Sci. 2012, 11, 1756-1766.

16. Kubin, R.F.; Fletcher, A.N. Fluorescence quantum yields of some rhodamine dyes. J. Lumin. 1982, 27, 455462.

(C) 2016 by the authors. Licensee MDPI, Basel, Switzerland. This article is an open access article distributed under the terms and conditions of the Creative Commons Attribution (CC BY) license (http://creativecommons.org/licenses/by/4.0/) 